\title{
Implications of Organic Amendments and Tillage of A Sandy Soil on its Physical Properties and C- Sequestration as well as Its Productivity of Wheat and Maize Grown Thereon
}

\author{
I.M. Farid", M.H.H. Abbas", Gh.S. Beheiry ${ }^{* *}$ and S.A.E. \\ Elcossy ${ }^{* * *}$ \\ "Soil and Water Department, Faculty of Agriculture, Benha \\ University, Benha and ${ }^{* *}$ Soil Conservation Department, Desert \\ Research Center, Cairo, Egypt.
}

\begin{abstract}
OIL organic matter is an essential component of fertility of soils, especially the sandy ones. It also accounts for increasing the emission of the greenhouse gases (GHG). Efficient managements of applied organic amendments to soil are required to reduce GHG emission. The current research aimed at investigating the effects of farm yard manure and compost applied at two different rates, i.e., 24 and $48 \mathrm{Mg} \mathrm{ha}^{-1}$ using shallow $(0-10 \mathrm{~cm})$ or deep $(0-20 \mathrm{~cm})$ tillage operations on improving the physical properties of the studied soil, carbon sequestration in soil and its relation to the wheat and maize yields. Increases in aggregate stability, available water content and the grain yields of wheat, as well as maize were obtained with the application of the organic amendments. Increasing the application rate resulted in more positive effects. The second degree equation seemed to be the best fitting model for predicting wheat and maize yields as affected by the rate of the applied organic C. Shallow tillage led to higher trapping of soil $\mathrm{CO}_{2}$ and more residual organic carbon in soil after harvest than the deep tillage did.
\end{abstract}

Keywords: Wheat, Maize, Farmyard manure, Compost, Soil tillage, $\mathrm{CO}_{2}$ trapping, Soil physical properties.

Wheat is an strategic commodity in Egypt and is mainly consumed in the Egyptian diet as bread (Kheralla et al., 2000). The Egyptian government is subsiding flour and bread (Gutner, 2002 and Ramadan \& Thomas, 2011), in spite of the national production of wheat accounts only for $56 \%$ self-sufficiency (Shehata and Mohammad, 2010). The Egyptian government fills the gap between the consumption and production by importing wheat from other countries (Seleiman et al., 2010). Maize is another important crop for human food as well as animal feed (Shiferaw et al., 2011 and Wu and Guclu, 2013). It is used in the production of bread in Egypt by mixing its flour with wheat flour (Ghoneim, 2012). Maize consumption in Egypt was estimated at 9.0 million mega grams during 2012/13 and the imports of maize were estimated at 5.0

Corresponding author: mohamed.abbas@fagr.bu.edu.eg 
million mega grams during 2011/12 (USDA, 2012). Accordingly, raising the production of wheat and maize became a national target in Egypt especially in the new reclaimed soils (mostly sandy desert soil) to meet the overgrowing demands on one hand and to decrease imports of these crops on the other hand.

Soil organic matter is essential for improving soil fertility under sustainable agricultural systems (Johnston et al., 2009), especially in sandy soils which suffer mainly from low fertility and poor plant productivity (Jaiarree et al., 2011). Increasing $\mathrm{N}$ or $\mathrm{P}$ content in soil could accelerate the decomposition of the organic matter in soil and thus increase crop production (Cleveland and Townsend, 2006). Organic amendments decrease soil bulk density and increase available water content in soil (Ozores-Hampton et al., 2011). On the other hand, application of organic residues might also account for increasing the emissions of the greenhouse gases (GHG). Thus, efficient managements of organic applications to soil is necessary to decrease such emissions (Burney et al., 2010).

The recent increases in global temperature indicates a future new phase of climate in which the enhanced greenhouse effect has the most influence on the atmosphere (Woodwell et al., 1998). Although, some gases, principally methane, nitrous oxide and chlorofluorocarbons are more important per molecule on climate than carbon dioxide emission, yet carbon dioxide emissions still account for $80 \%$ of the current greenhouse gas emissions (Lashof and Ahuja, 1990). Soil carbon sequestration is the process of increasing in the soil content of organic carbon due to the change in soil management (Powlson et al., 2011) and, to some extent, is affected by soil water conservation and soil fertility regulations (Lal, 2004 and Lal \& Kimble, 1997). The rate of soil C sequestration varies between 100 to $1000 \mathrm{~kg} \mathrm{ha}^{-1} \mathrm{yr}^{-1}$ depending on land use, soil properties, landscape position, climate, and cropping/farming systems (Lal, 2009).

The current research aims at investigating the effects of amending sandy soil with two sources of organic amendments, i.e., farm yard manure and compost at two different rates, i.e., 24 and $48 \mathrm{Mg} \mathrm{ha}^{-1}$ on soil physical properties and grain yield of wheat and maize. This study also considers the effects of the depth of tillage (shallow vs. deep tillage) on carbon sequestration in soil, and its relation with wheat and maize yields.

\section{Material and Methods}

\section{Material of study}

A representative surface soil sample $(0-30 \mathrm{~cm})$ of the area of study was collected prior to the winter and summer seasons, air dried and sieved to pass through a 2-mm sieve then analyzed for physical and chemical properties according to the standard methods outlined by Klute (1986) and Page et al. (1982). Physical and chemical properties of the studied soil are presented in Table 1. 
TABLE 1. Physical and chemical properties of the studied soil .

\begin{tabular}{|c|c|c|c|c|c|c|c|c|c|c|c|}
\hline 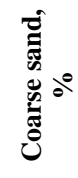 & 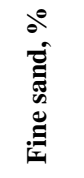 & $\begin{array}{l}\stackrel{0}{0} \\
\stackrel{=}{*}\end{array}$ & 完 & $\stackrel{\stackrel{\Xi}{E}}{\stackrel{E}{E}}$ & 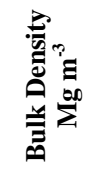 & $\underbrace{\infty}_{\substack{0 \\
0}}$ & 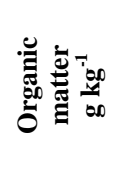 & 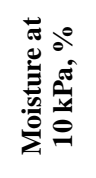 & 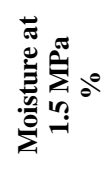 & 蓉 & 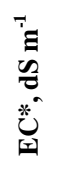 \\
\hline 42.26 & 43.28 & 13.28 & 1.18 & Sand & 1.67 & 6.15 & 3.25 & 14.99 & 5.56 & 8.25 & 3.65 \\
\hline
\end{tabular}

Two organic amendments, the first one was farmyard manure obtained from Balouza Experimental Station of Desert Research Center (DRC), while the other one was compost supplied by Maryut Experimental Station of the DRS. Physical and chemical characteristics of the organic amendments used in the study are shown in Table 2. Seeds of wheat (Triticum aesitivum L. c.v Giza 93) and maize ( Zea mays c.v. Giza 310) one way cross hybrid were supplied by the Crops Research Institute, Giza.

TABLE 2. Physico-chemical properties of the different amendments used in study.

\begin{tabular}{|c|c|c|c|c|c|c|c|}
\hline & pH * & $\begin{array}{c}\mathrm{EC}^{*} \\
\mathrm{dS} \mathrm{m}^{-1}\end{array}$ & $\begin{array}{c}\text { Bulk } \\
\text { density } \\
\mathrm{Mg} \mathrm{m}^{-3}\end{array}$ & $\begin{array}{c}\text { Organic } \\
\mathrm{C} \\
\mathrm{g} \mathrm{kg}^{-1}\end{array}$ & $\begin{array}{c}\text { Total } \\
\mathbf{N} \\
\mathrm{g} \mathrm{kg}^{-1}\end{array}$ & $\begin{array}{c}\text { Total } \\
\mathbf{P} \\
\mathrm{g} \mathrm{kg}^{-1}\end{array}$ & $\begin{array}{c}\text { Total } \\
\mathbf{K} \\
\mathrm{g} \mathrm{kg}^{-1}\end{array}$ \\
\hline $\begin{array}{c}\text { Farmyard } \\
\text { manure }\end{array}$ & 6.90 & 2.10 & 0.57 & 280 & 17.0 & 14.0 & 19.0 \\
\hline compost & 6.95 & 2.18 & 0.65 & 230 & 13.6 & 14.3 & 12.3 \\
\hline
\end{tabular}

*pH and EC: $1: 5$ w/w water extract.

\section{The field experiment}

A field experiment was conducted at El-Fardows valley, Southern East of El Qantra - North Sinai, for two successive seasons, i.e., winter season of 2009/2010 where the soil was under wheat and summer season of 2010 where the soil was under maize. The experimental design was a split plot design with three replicates, a plot area of $12 \mathrm{~m}^{2}$. Main plots were assigned to the depth of tillage by which the organic amendment was applied, i.e., surface tillage from $0-10$ and deep tillage from $10-20 \mathrm{~cm}$ and the sub-plots were assigned to the organic amendments, i.e., farmyard manure (FYM) and compost (CMPT), each applied at two rates, i.e., 24 and $48 \mathrm{Mg} \mathrm{ha}^{-1}$. A non amended treatment was also carried out. The applied organic amendments were thoroughly mixed throughout with soil before plowing.

\section{The wheat experiment}

Wheat seeds were sown on the $22^{\text {nd }}$ of November 2009 at the rate of $145 \mathrm{~kg} \mathrm{ha}^{-1}$. Ammonium nitrate fertilizer $\left(335 \mathrm{~g} \mathrm{~N} \mathrm{~kg}^{-1}\right)$ was added to all the experimental plots at a rate of $240 \mathrm{~kg} \mathrm{~N} \mathrm{ha}^{-1}$ at three equal doses, i.e., during planting, 30 days 
after planting and 60 days after planting. Superphosphate fertilizer $\left(68.9 \mathrm{~g} \mathrm{P} \mathrm{kg}^{-1}\right)$ was applied at a rate of $49 \mathrm{~kg} \mathrm{P}^{-1}$ during soil preparation. Potassium sulphate fertilizer $\left(400 \mathrm{~g} \mathrm{~K} \mathrm{~kg}^{-1}\right)$ was applied at a rate of $50 \mathrm{~kg} \mathrm{~K} \mathrm{ha}^{-1}$ at 30 days after planting. Plants were irrigated every 6 days interval using sprinkler irrigation system and all the cultivation practices were followed as recommended by the Ministry of Agriculture and Land Reclamation. Wheat was then harvested from all plots on the $22^{\text {nd }}$ of April and the grain yields were recorded.

\section{The maize experiment}

Maize seeds were sown was on $5^{\text {th }}$ of May 2010 at a rate of $48 \mathrm{~kg} \mathrm{ha}^{-1}$. Ammonium nitrate fertilizer $\left(335 \mathrm{~g} \mathrm{~N} \mathrm{~kg}^{-1}\right)$ was applied to all experimental plots at three equal doses, i.e., during planting, 30 days after planting and 60 days after planting at a rate of $360 \mathrm{~kg} \mathrm{~N} \mathrm{ha}^{-1}$. Super phosphate fertilizer $\left(68.9 \mathrm{~g} \mathrm{P} \mathrm{kg}^{-1}\right)$ was applied at a rate of $50 \mathrm{~kg} \mathrm{P} \mathrm{ha}{ }^{-1}$ during soil preparation. Potassium sulphate (400 $\mathrm{g} \mathrm{K} \mathrm{kg}^{-1}$ ) was added at a rate of $33 \mathrm{~kg} \mathrm{~K} \mathrm{ha}^{-1}$ at 30 days after planting. Plants were irrigated every 3 days interval using sprinkler irrigation system and all the cultivation practices were followed as recommended by the Ministry of Agriculture and Land Reclamation. Maize was harvested on the $26^{\text {th }}$ of August and the grain yields were recorded.

\section{Soil analysis}

Surface soil samples were collected from the rhizosphere of the grown plants in each experimental plot immediately after harvest, placed in plastic bags which were tightly closed to minimize the loss of soil $\mathrm{CO}_{2}$. Soil moisture tension was determined at $10 \mathrm{kPa}$ and $1.5 \mathrm{MPa}$ using the pressure membrane method as outlined by Stakman and van de Harst (1962). Available water content was calculated as the difference between soil moisture determined at $1.5 \mathrm{MPa}$ (considered as welting point) subtracted from the moisture content in soil measured at $10 \mathrm{kPa}$ (considered as field capacity for sandy soils). The organic matter content was determined in soil samples after cropping according to the modified Walkley and Black method (Page et al., 1982). The mean weight diameter (MWD) of the soil aggregates was determined according to Fonte et al. (2010). Measuring $\mathrm{CO}_{2}$ trapping in soil was taken as an indication of the metabolic activities of the soil microorganisms according to Pramer and Schmidt (1964) modified by Shehata (1972). Twenty five gram soil portions were placed in cylindrical polyethylene bags and brought to $60 \%$ of water holding capacity. The bag was hooked to a wire in the lower surface of a rubber plug fitted closely into neck of one liter Pyrex glass flask containing $30 \mathrm{~mL}$ of $\mathrm{NaOH} 0.05 \mathrm{~N}$ for trapping $\mathrm{CO}_{2}$. All flasks were incubated at $28 \pm 2{ }^{\circ} \mathrm{C}$ for $24 \mathrm{hr}$. Afterwards, 2-3 drops of phenolphthalein were added to the entrapped $\mathrm{CO}_{2}$ solution in the flask followed by titration against $\mathrm{HCl} 0.05 \mathrm{~N}$. Calculations of $\mathrm{CO}_{2}$ were carried out according to the following equation:

$$
\mu \mathrm{gCO}_{2} / \mathrm{g} \text {. dry soil/h }=(\mathrm{B}-\mathrm{T}) \mathrm{x} \frac{N_{\mathrm{HCl}} \times E q . \mathrm{Wt} .{ }_{\mathrm{CO}_{2}} \times 1000}{\text { sample weight } \mathrm{x} \text { incubation period }}
$$


Where: $\mathrm{B}=$ volume of $\mathrm{HCl}$ used in blank titration; $\mathrm{T}=$ volume of $\mathrm{HCl}$ used in the sample titration; $N=$ normality of $\mathrm{HCl}$; Eq.Wt. ${ }_{\mathrm{CO} 2}=$ molecular weight of $\mathrm{CO}_{2}$; sample weight =weight of the used soil sample, $25 \mathrm{~g}$; incubation period $=$ the incubation period in hours, $24 \mathrm{hr}$.

\section{Data analysis}

The relations between soil $\mathrm{C}$ and either of the wheat or maize yields were plotted graphically for each depth of soil application. The soil $\mathrm{C}$ was calculated during the winter season through the summation of initial $\mathrm{C}$ in soil plus the $\mathrm{C}$ of the applied organic amendments; whereas, soil $\mathrm{C}$ was calculated during the summer season through the summation of the residual $\mathrm{C}$ in soil after wheat cropping plus organic carbon of the organic amendment at its applied rate. The obtained relations were fitted to four mathematical models. The equations used in this study according to number Wallace (2010) were (1) the linear first degree equation $y=a+b x$ where $\mathrm{a}$ and $\mathrm{b}$ are constants (2) the quadratic second degree equation $y=a+b x+c x^{2}$ where the coefficients $\mathrm{a}, \mathrm{b}$ and $\mathrm{c}$ are real numbers $\neq$ zero $(3)$ the exponential equation $y=\mathrm{e}^{\mathrm{ax}}$ where the coefficient $\mathrm{e}$ is the approximately 2.72 and "a" is a constant (4) fractional power $y=x^{a}$ where " $a$ " is a negative. The standard error of estimate (S.E.) for the mathematical models were calculated according to Shariatmadari et al. (2006) and Abbas and Salem (2011) as follows:

$$
S E=\left[\sum\left(Q_{t}-Q_{t}{ }^{l}\right)^{2} /(n-2)\right]^{1 / 2}
$$

$Q_{t}$ and $Q_{t}{ }^{t}$ are the obtained and predicted grain yields of wheat and maize, respectively, and $\mathrm{n}$ is the number of measurements.

\section{Results}

Effect of type and rate of the applied amendments and the tillage depth on the yield of wheat grain and straw

Data presented in Table 3 reveal that the grain yields of wheat and maize increased significantly with the application of either of the farmyard manure (FYM) or the compost (CMPT) amendment. In this concern, FYM applications recorded significantly higher increases in the grain yields than those attained owing to application of CMPT. The average increases in the grain yield due to FYM and CMPT at a rate of $24 \mathrm{Mg} \mathrm{ha}^{-1}$ were 54 and $45 \%$, respectively for wheat and 31 and $26 \%$, respectively for maize. In spite of doubling the rate of the applied FYM and CMPT from 24 to $48 \mathrm{Mg} \mathrm{ha}^{-1}$, the obtained increases did not exceed 17 and 21\%, respectively for wheat grain yield and 15 to $12 \%$, respectively for maize grain yield. Considering effect of tillage depth, shallow tillage caused more significant increases in grain yields of wheat and maize than deep tillage (about $6 \%$ increase in the grain yield of wheat and maize). 
TABLE 3. Yields of wheat and maize grain $\left(\mathrm{Mg} \mathrm{ha}^{-1}\right)$ as affected by type and rate of the applied organic amendment and depth of tillage .

\begin{tabular}{|c|c|c|c|c|c|c|c|}
\hline \multirow{3}{*}{$\begin{array}{c}\text { Amendment } \\
\text { (A) }\end{array}$} & \multirow{3}{*}{$\begin{array}{c}\text { Rate of } \\
\text { application } \\
(\mathbf{R}), \mathrm{Mg} \mathrm{ha}^{-1}\end{array}$} & \multicolumn{6}{|c|}{ Depth of tillage (T) } \\
\hline & & \multicolumn{3}{|c|}{ Winter Season (Wheat) } & \multicolumn{3}{|c|}{ Summer season (Maize) } \\
\hline & & Shallow & Deep & Mean & Shallow & Deep & Mean \\
\hline \multirow{3}{*}{$\begin{array}{l}\text { Farmyard } \\
\text { manure }\end{array}$} & & 6.79 & 6.36 & 6.58 & 7.24 & 6.88 & 7.06 \\
\hline & 48 & 7.81 & 7.62 & 7.72 & 8.17 & 7.88 & 8.03 \\
\hline & mean & 7.30 & 6.99 & 7.15 & 7.71 & 7.38 & 7.55 \\
\hline \multirow{3}{*}{ Compost } & 24 & 6.36 & 6.02 & 6.19 & 6.95 & 6.69 & 6.82 \\
\hline & 48 & 7.64 & 7.38 & 7.51 & 7.74 & 7.50 & 7.62 \\
\hline & Mean & 7.00 & 6.70 & 6.85 & 7.35 & 7.10 & 7.23 \\
\hline \multicolumn{2}{|c|}{ Non-amended } & 4.49 & 4.14 & 5.32 & 5.55 & 5.24 & 5.40 \\
\hline \multicolumn{2}{|c|}{ Grand mean } & 6.60 & 6.30 & 6.45 & 7.13 & 6.84 & 6.99 \\
\hline \multicolumn{8}{|c|}{ Means of the rate of application } \\
\hline \multirow{2}{*}{\multicolumn{2}{|c|}{$\begin{array}{l}\text { Rate of application } \\
\text { Non-amended }\end{array}$}} & \multicolumn{2}{|c|}{ Winter season } & \multicolumn{2}{|c|}{ Summer season } & & \\
\hline & & 4.32 & & 5.40 & & & \\
\hline & 6.38 & & 6.94 & & & \\
\hline & $\begin{array}{l}24 \\
48 \\
\end{array}$ & 7.61 & & 7.83 & & & \\
\hline LSD (0.05) & $\mathrm{A}$ & $\mathrm{R}$ & $\mathrm{T} \times \mathrm{A}$ & $\mathrm{T} \times \mathrm{R}$ & $\mathrm{A} \times \mathrm{R}$ & $\mathrm{T} \times \mathrm{A} \times \mathrm{R}$ & \\
\hline Winter & 0.010 & 0.009 & 0.015 & 0.009 & 0.012 & 0.017 & \\
\hline Summer & 0.007 & 0.006 & 0.009 & 0.007 & 0.009 & 0.013 & \\
\hline
\end{tabular}

Effect of type and rate of the applied amendments and the tillage depth on the available water in soil

Table 4 shows that application of the soil amendments at the low rate increased significantly available water content of soil by an average of $19 \%$ during the winter and $17 \%$ during the summer seasons. The higher rate of application of the organic amendments caused more increases in the available water content (averaging 35\% in winter and $26 \%$ in summer). Concerning the effects of the tillage depth on soil available water, it was found that the shallow tillage caused significant increases in the available water content than did the deep tillage (averaging about $4 \%$ in both seasons).

Effect of type and rate of the applied amendments and the depth of tillage on mean weight diameter (MWD) of soil aggregates

Data shown in Table 5 reveal that values of the mean weight diameter (MWD) of soil aggregates increased significantly with the application of FYM as well as compost. The average increases in MWD due to application of FYM and CMPT at a rate of $24 \mathrm{Mg} \mathrm{ha}^{-1}$ were about 1.24 fold during the winter season and 1.25 fold during the summer one. Increasing the rate of application from 24 to 48 $\mathrm{Mg} \mathrm{ha}^{-1}$ caused significant increases in MWD; however such increases were very low (2-7\% increase in MWD). On the other hand, the shallow tillage caused significant higher increases in values of MWD than the deep tillage did (about $10 \%$ increase in MWD during both the winter and the summer seasons).

Egypt. J. Soil Sci. 54, No. 2 (2014) 
TABLE 4 . Soil available water content as affected by the type and rate of the applied organic amendment and the depth of tillage.

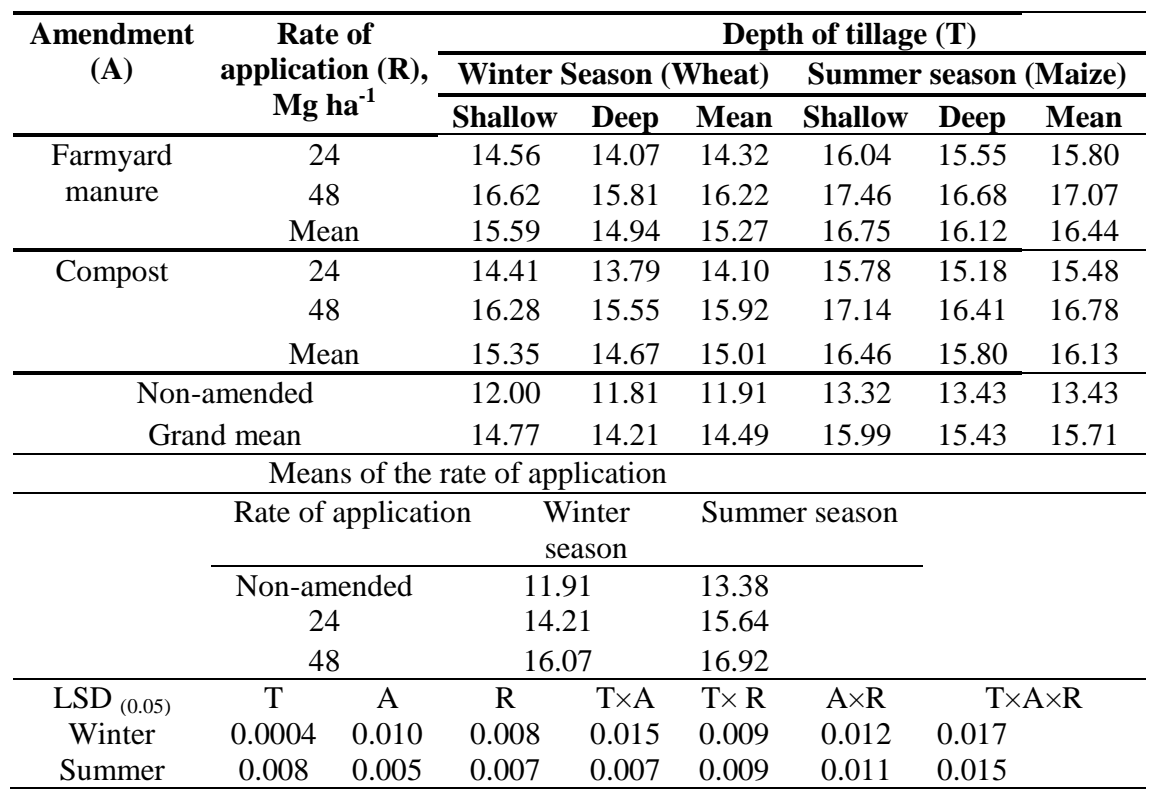

TABLE 5. Soil aggregate mean weight diameter as affected by type and rate of the applied organic amendment and the depth of tillage .

\begin{tabular}{|c|c|c|c|c|c|c|c|}
\hline \multirow{3}{*}{$\begin{array}{l}\text { Amendment } \\
\text { (A) }\end{array}$} & \multirow{3}{*}{$\begin{array}{c}\text { Rate of } \\
\text { application (R), } \\
\operatorname{Mg~ha}^{-1}\end{array}$} & \multicolumn{6}{|c|}{ Depth of tillage (T) } \\
\hline & & \multicolumn{3}{|c|}{ Winter Season (Wheat) } & \multicolumn{3}{|c|}{ Summer season (Maize) } \\
\hline & & Shallow & Deep & Mean & Shallow & Deep & Mean \\
\hline \multirow{3}{*}{$\begin{array}{l}\text { Farmyard } \\
\text { manure }\end{array}$} & 24 & 1.00 & 0.95 & 0.98 & 1.01 & 0.99 & 1.00 \\
\hline & 48 & 1.10 & 0.99 & 1.05 & 1.05 & 1.01 & 1.03 \\
\hline & Mean & 1.05 & 0.97 & 1.01 & 1.03 & 1.00 & 1.02 \\
\hline \multirow[t]{3}{*}{ Compost } & 24 & 0.98 & 0.93 & 0.96 & 1.02 & 0.98 & 0.98 \\
\hline & 48 & 1.06 & 0.96 & 1.01 & 1.04 & 1.01 & 1.01 \\
\hline & Mean & 1.02 & 0.95 & 0.99 & 1.03 & 1.00 & 1.00 \\
\hline \multicolumn{2}{|l|}{ Non-amended } & 0.82 & 0.74 & 0.78 & 0.84 & 0.76 & 0.76 \\
\hline \multirow[t]{2}{*}{ Grand mean } & & 0.99 & 0.91 & 0.95 & 0.99 & 0.95 & 0.95 \\
\hline & Means of the r & ate of ap & cation & & & & \\
\hline \multicolumn{2}{|c|}{ Rate of application } & \multicolumn{2}{|c|}{ Winter season } & \multicolumn{2}{|c|}{ Summer season } & & \\
\hline & Non-amended & 0.78 & & \multicolumn{2}{|c|}{0.81} & & \\
\hline & 24 & 0.97 & & \multicolumn{2}{|l|}{1.00} & & \\
\hline & 48 & 1.03 & & \multicolumn{2}{|l|}{1.03} & & \\
\hline LSD (0.05) & A & $\mathrm{R}$ & $\mathrm{T} \times \mathrm{A}$ & $\mathrm{T} \times \mathrm{R}$ & $\mathrm{A} \times \mathrm{R}$ & & \\
\hline Winter & 0.021 & 0.028 & 0.030 & 0.032 & 0.040 & & \\
\hline Summer & $\begin{array}{ll}0.0005 & 0.001 \\
\end{array}$ & 0.0007 & 0.001 & 0.001 & 0.001 & & 01 \\
\hline
\end{tabular}


Effect of type and rate of the applied amendments and the depth of tillage on the residual organic carbon in soil after cropping

Data presented in Table 6 show that application of either of FYM or CMPT markedly increased the organic carbon content (OC) in soil at the end of each growing season by 70 and $54 \%$, respectively during the winter season corresponding to 70 and $61 \%$, respectively during the summer season. Increasing the rate of application of either FYM or compost from 24 to $48 \mathrm{Mg} \mathrm{ha}^{-1}$ showed further significant increases in the OC; however such increases were only $15 \%$ during winter and $12 \%$ during summer. On the other hand, significant increases were found in OC due to shallow tillage vs. deep tillage (about 13\% during winter and $8 \%$ during summer).

TABLE 6. Organic carbon in soil $\left(\mathrm{g} \mathrm{kg}^{-1}\right)$ at end of the growing seasons as affected by type and rate of the applied organic amendment and the depth of tillage.

\begin{tabular}{|c|c|c|c|c|c|c|c|c|}
\hline \multirow{3}{*}{$\begin{array}{l}\text { Amendment } \\
\text { (A) }\end{array}$} & \multirow{3}{*}{\multicolumn{2}{|c|}{$\begin{array}{c}\text { Rate of } \\
\text { application } \\
(\mathbf{R}), \mathrm{Mg} \mathrm{ha}^{-1}\end{array}$}} & \multicolumn{6}{|c|}{ Depth of tillage (T) } \\
\hline & & & \multicolumn{3}{|c|}{$\begin{array}{c}\text { Winter Season } \\
\text { (Wheat) }\end{array}$} & \multicolumn{3}{|c|}{$\begin{array}{c}\text { Summer season } \\
\text { (Maize) }\end{array}$} \\
\hline & & & Shallow & Deep & Mean & Shallow & Deep & Mean \\
\hline \multirow{3}{*}{$\begin{array}{l}\text { Farmyard } \\
\text { manure }\end{array}$} & \multicolumn{2}{|c|}{24} & 6.05 & 5.35 & 5.70 & 4.55 & 3.50 & 4.03 \\
\hline & \multicolumn{2}{|c|}{48} & 6.90 & 6.20 & 6.55 & 7.15 & 6.55 & 6.85 \\
\hline & \multicolumn{2}{|c|}{ Mean } & 6.48 & 5.78 & 6.13 & 5.85 & 5.03 & 5.44 \\
\hline \multirow[t]{3}{*}{ Compost } & \multicolumn{2}{|c|}{24} & 5.45 & 4.85 & 5.15 & 7.90 & 7.40 & 7.65 \\
\hline & \multicolumn{2}{|c|}{48} & 6.30 & 5.65 & 5.98 & 6.55 & 6.45 & 6.50 \\
\hline & \multicolumn{2}{|c|}{ Mean } & 5.88 & 5.25 & 5.57 & 7.23 & 6.93 & 7.08 \\
\hline \multicolumn{3}{|c|}{ Non-amended } & 3.80 & 2.90 & 3.35 & 4.55 & 3.50 & 4.02 \\
\hline \multicolumn{3}{|c|}{ Grand mean } & 5.70 & 4.99 & 5.25 & 6.14 & 5.48 & 5.81 \\
\hline \multicolumn{9}{|c|}{ Means of the rate of application } \\
\hline \multicolumn{3}{|c|}{ Rate of application } & \multicolumn{2}{|c|}{ Winter season } & \multicolumn{2}{|c|}{ Summer season } & & \\
\hline & \multicolumn{2}{|c|}{$\begin{array}{c}\text { Non- } \\
\text { amended }\end{array}$} & 3.35 & & 4.03 & & & \\
\hline & \multicolumn{2}{|c|}{24} & 5.43 & & 5.84 & & & \\
\hline & \multicolumn{2}{|c|}{48} & 6.26 & & 6.68 & & & \\
\hline $\operatorname{LSD}_{(0.05)}$ & $\mathrm{T}$ & $\mathrm{A}$ & $\mathrm{R}$ & $\mathrm{T} \times \mathrm{A}$ & $\mathrm{T} \times \mathrm{R}$ & $\mathrm{A} \times \mathrm{R}$ & \multicolumn{2}{|c|}{$\mathrm{T} \times \mathrm{A} \times \mathrm{R}$} \\
\hline Winter & $\begin{array}{c}0.0 \\
10\end{array}$ & 0.005 & 0.009 & 0.007 & 0.010 & 0.013 & \multicolumn{2}{|c|}{0.019} \\
\hline Summer & $\begin{array}{c}0.0 \\
18\end{array}$ & 0.005 & 0.006 & 0.008 & 0.007 & 0.009 & \multicolumn{2}{|l|}{0.013} \\
\hline
\end{tabular}

Effect of type and rate of the applied amendments and the depth of tillage on $\mathrm{CO}_{2}$ - trapped in soil

Table 7 reveals that trapped $\mathrm{CO}_{2}$ in soil increased with the application of either of FYM or CMPT amendment. The average increases in trapped $\mathrm{CO}_{2}$ due to the application of FYM and CMPT at rates of $24 \mathrm{Mg} \mathrm{ha}^{-1}$ were 292 and $264 \%$, respectively during the winter season corresponding to 285 and $260 \%$, respectively during the summer season. Such increases seemed to be associated Egypt. J. Soil Sci. 54, No. 2 (2014) 
with the rate of the applied organic amendment with significant increases of about $20 \%$ for increasing the rate of application from 24 to $48 \mathrm{Mg} \mathrm{ha}^{-1}$ for both amendments. Trapped $\mathrm{CO}_{2}$ increased in soil under all treatments with shallow tillage to higher values than those attained due to the deep tillage. Although the increases in $\mathrm{CO}_{2}$-trapping per hour were around $10 \%$ for shallow tillage vs. deep tillage during the winter and summer seasons; yet, such increases seemed to be more pronounced in determining the yields of wheat or maize.

TABLE 7. Trapped soil $\mathrm{CO}_{2}(\mu \mathrm{g} \mathrm{CO} / \mathrm{g}$.dry soil/h) as affected by type and rate of the applied organic amendment and the depth of tillage.

\begin{tabular}{|c|c|c|c|c|c|c|c|c|}
\hline \multirow{3}{*}{$\begin{array}{l}\text { Amendment } \\
\text { (A) }\end{array}$} & \multirow{3}{*}{\multicolumn{2}{|c|}{$\begin{array}{c}\text { Rate of } \\
\text { application } \\
\text { (R), } \mathrm{Mg} \mathrm{ha}^{-1}\end{array}$}} & \multicolumn{6}{|c|}{ Depth of tillage (T) } \\
\hline & & & \multicolumn{3}{|c|}{$\begin{array}{c}\text { Winter Season } \\
\text { (Wheat) }\end{array}$} & \multicolumn{3}{|c|}{$\begin{array}{c}\text { Summer season } \\
\text { (Maize) }\end{array}$} \\
\hline & & & Shallow & Deep & Mean & Shallow & Deep & Mean \\
\hline \multirow{3}{*}{$\begin{array}{l}\text { Farmyard } \\
\text { manure }\end{array}$} & \multicolumn{2}{|c|}{24} & 24.75 & 22.24 & 23.50 & 27.99 & 24.53 & 26.26 \\
\hline & \multicolumn{2}{|c|}{48} & 29.67 & 27.35 & 28.51 & 31.65 & 28.89 & 30.27 \\
\hline & \multicolumn{2}{|c|}{ Mean } & 27.21 & 24.80 & 26.01 & 29.82 & 26.71 & 28.27 \\
\hline \multirow[t]{3}{*}{ Compost } & \multicolumn{2}{|c|}{24} & 22.51 & 20.02 & 21.27 & 25.75 & 22.19 & 23.97 \\
\hline & \multicolumn{2}{|c|}{48} & 27.38 & 25.06 & 26.22 & 29.38 & 26.75 & 28.07 \\
\hline & \multicolumn{2}{|c|}{ Mean } & 24.95 & 22.54 & 23.75 & 27.57 & 24.47 & 26.02 \\
\hline \multicolumn{3}{|l|}{ Non-amended } & 8.75 & 7.35 & 8.05 & 9.90 & 8.55 & 9.23 \\
\hline \multicolumn{3}{|l|}{ Grand mean } & 22.61 & 20.40 & 21.51 & 24.93 & 22.18 & 23.56 \\
\hline \multicolumn{9}{|c|}{ Means of the rate of application } \\
\hline \multicolumn{3}{|c|}{ Rate of application } & \multicolumn{2}{|c|}{ Winter season } & \multicolumn{2}{|c|}{$\begin{array}{c}\text { Summer } \\
\text { season }\end{array}$} & & \\
\hline \multicolumn{3}{|l|}{ Non-amended } & \multicolumn{2}{|c|}{8.05} & \multicolumn{2}{|c|}{9.23} & & \\
\hline 24 & & & \multicolumn{2}{|c|}{22.38} & \multicolumn{2}{|c|}{24.63} & & \\
\hline 48 & & & \multicolumn{2}{|c|}{27.37} & \multicolumn{2}{|c|}{28.94} & & \\
\hline $\operatorname{LSD}_{(0.05)}$ & $\mathrm{T}$ & A & $\mathrm{R}$ & $\mathrm{T} \times \mathrm{A}$ & $\mathrm{T} \times \mathrm{R}$ & $\mathrm{A} \times \mathrm{R}$ & \multicolumn{2}{|c|}{$\mathrm{T} \times \mathrm{A} \times \mathrm{R}$} \\
\hline Winter & 0.018 & 0.004 & 0.006 & 0.006 & 0.007 & 0.009 & 0.012 & \\
\hline Summer & 0.116 & 0.070 & 0.063 & 0.008 & 0.010 & 0.013 & 0.018 & \\
\hline
\end{tabular}

The relation between wheat and maize grain yields as affected by $C$ content in soil and the depth of tillage

The relations between the obtained yields of either wheat or maize and the rate of soil $\mathrm{C}$ were plotted graphically for each type of soil tillage, i.e., shallow vs. deep tillage (Fig. 1).

Four mathematical models were fitted to these relations to find out the best fitting model to explain such relations and the calculated correlation coefficients $\mathrm{r}^{2}$ and standard error of estimates (S.E.) of these fitting models are shown in Table 8 . Based on the highest $r^{2}$ values and the lowest values of standard error of estimates (S.E.), the second degree function seemed to be the best fitting model for describing the relation between the obtained wheat grain yield in relation with the rate of soil $\mathrm{C}$ under the shallow and deep tillage. 

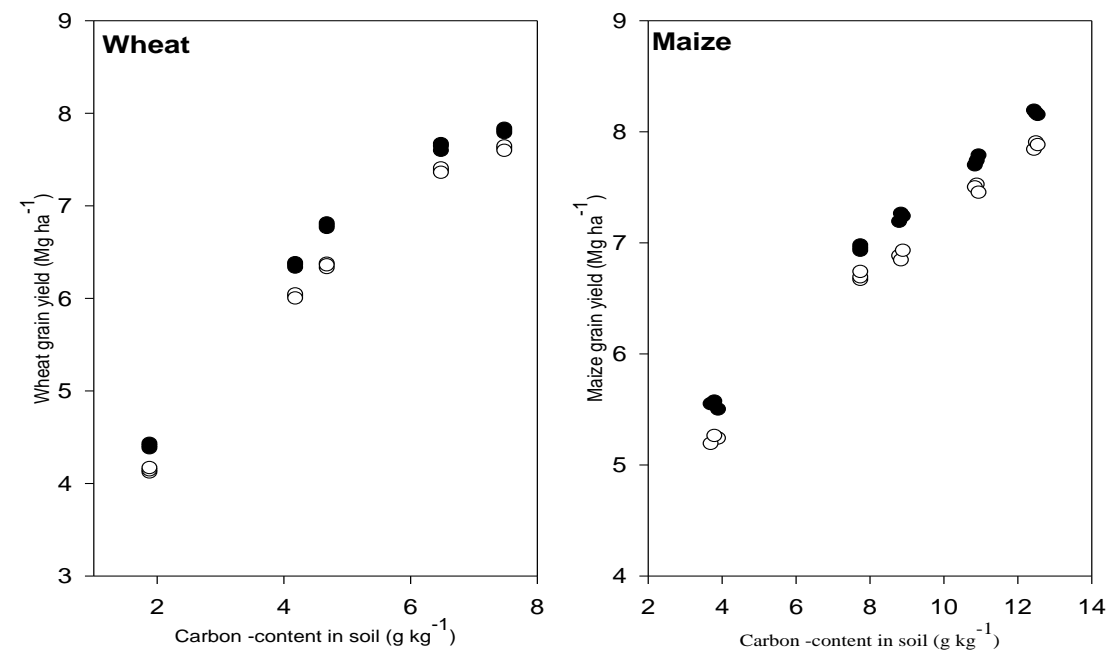

- Shallow tillage (ST)

Fig. 1. Wheat (A) and maize (B) grain yields as affected by type and rate of the applied organic amendment and the depth of tillage .

TABLE 8. Correlation coefficients of the wheat and maize grain yields as affected by type and rate of the applied organic amendment and the depth of tillage.

\begin{tabular}{lccccccccc}
\hline & \multicolumn{4}{c}{ Wheat } & \multicolumn{4}{c}{ Maize } \\
\hline & \multicolumn{4}{c}{ Deep tillage } & \multicolumn{2}{c}{$\begin{array}{c}\text { Shallow } \\
\text { tillage }\end{array}$} & \multicolumn{2}{c}{ Deep tillage } & \multicolumn{2}{c}{$\begin{array}{c}\text { Shallow } \\
\text { tillage }\end{array}$} \\
& $r^{2}$ & S.E. & $r^{2}$ & S.E. & $r^{2}$ & S.E. & $r^{2}$ & S.E. \\
\hline First degree & 0.970 & 0.232 & 0.946 & 0.305 & 0.987 & 0.110 & 0.989 & 0.101 \\
Second degree & 0.999 & 0.049 & 0.999 & 0.051 & 0.996 & 0.061 & 0.998 & 0.048 \\
The exponential & 0.000 & 2.100 & 0.000 & 2.338 & 0.000 & 2.278 & 0.000 & 2.456 \\
The fractional power & 0.995 & 0.095 & 0.986 & 0.155 & 0.997 & 0.058 & 0.997 & 0.049 \\
\hline
\end{tabular}

The calculated quadratic second order relations were:

$$
\begin{aligned}
& y=2.084+1.202 x-0.06 x^{2} \\
& y=2.093+1.373 x-0.09 x^{2}
\end{aligned}
$$

Eq. 1 (Deep tillage)

Eq. 2 (Shallow tillage)

By differentiating equations 1 and 2, we can obtain the following equations

$\frac{d y}{d x}=1.202-0.12 x$

$\frac{d y}{d x}=1.373-0.18 x$

Eq. 3 (Deep tillage)

Eq. 4 (Shallow tillage)

Thus, the ultimate outcomes of the organic amendments (in the term of organic $\mathrm{C}$ ) on the wheat grain yield can be obtained when value of the calculated

Egypt. J. Soil Sci. 54, No. 2 (2014) 
$\underline{d y}$

$d x$ exceeds one, afterwards the yield decreases. The calculated $\mathrm{x}$ values for these turning points were 10.02 and $7.63 \mathrm{~g} \mathrm{C} \mathrm{kg}^{-1}$ under deep and shallow tillage, respectively. After considering the initial content of soil $\mathrm{C}\left(1.89 \mathrm{~g} \mathrm{~kg}^{-1}\right)$, the required amounts become 8.14 and $5.785 \mathrm{~g} \mathrm{~kg}^{-1}$ for deep and shallow tillage, respectively. These amounts could be considered on basis of the organic amendments rather than organic $\mathrm{C}$ as 84 and $69 \mathrm{~kg} \mathrm{ha}^{-1}$ of CMPT and FYM, respectively required under deep tillage; whereas, only 60 and $49 \mathrm{~kg} \mathrm{ha}^{-1}$ of the respective amendments are required under shallow tillage. In case of maize, both the second degree equations seemed to be the most fitting models for describing the obtained grain yields of maize as affected by the $\mathrm{C}$ content of soil. Probably, the fraction power could be the most appropriate model for describing maize grain under continuous organic farming. Anyhow, the maximum amounts of the organic amendments required for obtaining the highest possible grain yield seemed to be far higher than the normal application rates, accordingly, the calculations of these amounts were neglected in the current research.

\section{Discussion}

Application of the organic amendments, i.e., FYM and CMPT improved significantly the investigated soil physical properties, especially at the higher application rate of these organic amendments. Organic amendments increased the mean weight diameter (MWD) of the soil aggregates and also available water content. "MWD" is considered a reliable indicator for the stability of aggregates in soil, i.e., high MWD value indicates high aggregate stability. The diffusion of the organic substances within the soil aggregates would increase the inter-particular cohesion force besides the large labile organic pool of these amendments would stimulate the microbial activity in soil which leads to increased water repellency (Annabi et al., 2007). Marked effect of applied organic amendments on increasing available water content in soil was reported by Mylavarapu and Zinati (2009) and Weber et al. (2007), especially in sandy soil which suffers from low water retention (Andry et al., 2009). The increases in yields of wheat and maize noticed in the current study owing to the application of the organic amendments agree with findings reported by Cherif et al. (2009), Alemazadeh and Kazemeini (2010) and Blaser et al. (2012). Rasool et al. (2008), Anyanzwa et al. (2010) and Chivenge et al. (2011) reported significant increases in maize productivity due to application of the organic amendments. Treatments receiving the organic amendments, especially at the higher application rates showed significant higher organic carbon after cropping. This finding agrees with that of Majumder et al. (2008) and Zhao et al. (2009) who reported significant increases in organic carbon upon FYM applications and Steiner et al. (2007) who found increases in organic carbon with compost application. Another component of the soil $\mathrm{C}$ in soil is the $\mathrm{CO}_{2}$. This fraction results from the respiration of plant roots and soil microorganisms (Ivo and Salcedo, 2012) and its emission is considered the main route of $\mathrm{C}$ loss from soil to the atmosphere (Parkin and Kaspar, 2003). Thus, determining the $\mathrm{CO}_{2}$ trapped in 
soil might give estimates of the impacts of the different soil management practices on soil organic C (Fortin et al., 1996).

Application of large amounts of organic matter to soil requires better management to attain the premier effects of these amendments on the physical properties of the sandy soils to achieve highest possible grain yield and, avoid more emissions of the green house gases. In this concern, sequestration of carbon in soil might be affected by soil surface managements (Lal, 2004 and Lal \& Kimble, 1997). Increases in the sequestered $\mathrm{CO}_{2}$ were noticed due to the change from conventional tillage to no-tillage (Ghimire et al., 2011, McCarl and Schneider, 2001 and West \& Post, 2002). The two soil tillage methods, i.e., shallow and deep tillage would reflect the effects on $\mathrm{C}$-sequestration in soil. The shallow tillage increased the mean weight diameter of soil aggregates, available water content in soil and $\mathrm{CO}_{2}$ trapped in soil. Also, higher grain yields of wheat and maize together with increasing the content of reserved organic carbon in soil after cropping were obtained in this study with shallow tillage rather than deep tillage. Kihara et al. (2011) reported also significant higher increases in the mean weight diameter of the aggregates and maize productivity with shallow tillage rather than deep tillage. However, Blaser et al. (2012) found no significant effect for the intensive tillage, moderate tillage or no tillage on the wheat yield. Concerning the residual organic carbon after cropping. Sainju et al. (2011) found that it increased in soil under reduced tillage. Also, Sommer et al. (2011) reported that the application of organic amendments can build-up soil organic matter under shallow tillage rather than the conventional moldboard plowing. Potentiality of $\mathrm{C}$ sequestration in soil depends on its affinity to store and accumulate humic substances in soil (Swift, 2001). Probably, the deep tillage accelerated the losses of organic matter from soil than the shallow tillage (Melero et al., 2012).

\section{Conclusion}

Amending soil with organic materials is of high importance for increasing aggregate stability in sandy soil and increasing available water content. Such amendments increased the grain yields of wheat and maize under the efficient irrigation system (sprinkler irrigation). Increasing the application rate of the organic amendments from 24 to $48 \mathrm{Mg} \mathrm{ha}^{-1}$ resulted in further improvements in the studied physical properties of the soil and recorded higher grains yields of wheat and maize. Efficient management and appropriate rates of amendment application would be of vital importance for maximizing the outcomes of these amendments and, at the same time, reducing the emissions of the green house gases. Accordingly, the relations between the obtained yields of either wheat or maize and the C-content in soil were plotted graphically for each application depth, i.e., surface shallow vs. deep tillage and four mathematical models were fitted to these relations. The results showed that the second degree equation was the best fitting model for wheat cropping; whereas, two models, i.e., second degree and the fractional power seemed to be the best fitting models for maize

Egypt. J. Soil Sci. 54, No. 2 (2014) 
cropping. In general, the applied amounts of the organic amendments were still lower than the calculated amounts of organic amendments required for maximum yield. On the other hand, the shallow tillage seemed to be more effective than deep tillage in increasing the benefits of soil carbon, at least under the used application rates of the soil amendments. The shallow tillage led to higher reservation of organic carbon in soil and trapped more soil $\mathrm{CO}_{2}$ than did the deep tillage, consequently the obtained grain yields of wheat and maize caused by shallow tillage were higher than those attained with deep tillage.

Acknowledgement: The authors would like to express their deep thanks to Prof. Dr. Hassan H. Abbas and Prof. Dr. Aly A. Abdel Salam Soils Department, Benha University, Egypt for their help with this study.

\section{References}

Abbas, M.H.H. and Salem, H.M. (2011) Kinetics of iron retention by Typic Torriorthent and Typic Haplocalcid soils supplied with some micronutrients. Annals of Agric. Sci., Moshtohor 49: 301-311.

Alemzadeh, A. and Kazemeini, S.A. (2010) Effect of organic and inorganic fertilizers on grain yield and protein banding pattern of wheat. Aust. J. Crop Sci. 4: 384-389.

Andry, H., Yamamoto, T., Irie, T., Moritani, S., Inoue, M. and Fujiyama, H. (2009) Water retention, hydraulic conductivity of hydrophilic polymers in sandy soil as affected by temperature and water quality. J Hydrol. 373: 177-183.

Annabi, M., Houot, S., Francou, C., Poitrenaud, M. and Le Bissonnais, Y. (2007) Soil aggregate stability improvement with urban composts of different maturities. Soil Sci. Soc. Am. J .71: 413-423.

Anyanzwa, H., Okalebo, J. R., Othieno, C.O., Bationo, A., Waswa, B.S. and Kihara, J. (2010) Effects of conservation tillage, crop residue and cropping systems on changes in soil organic matter and maize-legume production: a case study in Teso District. Nutr. Cycl. Agroecosys 88: 39-47.

Baker, J.M., Ochsner, T.E., Venterea, R.T. and Griffis, T.J. ( 2007) Tillage and soil carbon sequestration-What do we really know? Agric. Ecosyst. Environ. 118: 1-5.

Blaser, B.C., Singer, J.W. and Gibson, L.R. (2012) Winter wheat and red clover intercrop response to tillage and compost amendment. Crop Sci. 52: 320-326.

Burney, J.A., Davis, S.J. and Lobell, D.B. (2010) Greenhouse gas mitigation by agricultural intensification. PNAS 107 : 12052-12057.

Cherif, H., Ayari, F., Ouzari, H., Marzorati, M., Brusetti, L., Jedidi, N., Hassen, A. and Daffonchio, D. (2009) Effects of municipal solid waste compost, farmyard manure and chemical fertilizers on wheat growth, soil composition and soil bacterial characteristics under Tunisian arid climate. Eur. J. Soil. Biol. 45: 138-145. 
Chivenge, P., Valauwe, B. and Six, J. (2011) Does the combined application of organic and mineral nutrient sources influence maize productivity? A meta-analysis. Plant Soil 342: 1-30.

Cleveland, C.C. and Townsend, A.R. (2006) Nutrient additions to a tropical rain forest drive substantial soil carbon dioxide losses to the atmosphere. Proceedings of the National Academy of Sciences 103: 10316-10321.

Fonte, S.J., Barrios, E. and Six, J. (2010) Earthworms, soil fertility and aggregateassociated soil organic matter dynamics in the Quesungual agroforestry system. Geoderma 155: 320-328.

Fortin, M.C., Rochette, P. and Pattey, E. (1996) Soil carbon dioxide fluxes from onvCentional and no-tillage small-grain cropping systems. Soil. Sci. Soc. Am. J. 60: $1541-1547$.

Ghimire, R., Adhikari, K., Chen, S. Shah and Dahal, K. (2011) Soil organic carbon sequestration as affected by tillage, crop residue, and nitrogen application in ricewheat rotation system. Paddy Water Environ. 10: 95-102.

Ghoneim, A.F. (2012) The political economy of food price policy in Egypt. The UNUWIDER project on the Political Economy of Food Price Policy. Working Paper No. 2012/96.

Gutner, T. (2002) The political economy of food subsidy reform: the case of Egypt. Food Policy 27: 455-476.

Ivo, W.M.P.M. and Salcedo, I.H. (2012) Soil CO2 flux: a method comparison of closed static chambers in a sugarcane field. Rev. Bras Ciênc Solo 36: 421-426.

Jaiarree, S., Chidthaisong, A., Tangtham, N., Polprasert, C., Sarobol, E. and Tyler, S.C. (2011) Carbon budget and sequestration potential in a sandy soil treated with compost. Land Degrad Dev .

Johnston, A.E., Poultonm, P.R. and Coleman, K. (2009) Soil organic matter: its importance in sustainable agriculture and carbon dioxide fluxes. Adv. Agron. 101: 1-57.

Kheralla, M., Löfgren, H., Gruhn, P. and Reeder, M.M. (2000) Wheat policy reform in Egypt : adjustment of local markets and options for future reforms. International Food Policy Research Institute (IFPRI). Research Report 115, Washington, D.C.

Kihara, J., Bationo, A., Mugendi, D.N., Martius, C. and Vlek, P.L.G. (2011) Conservation tillage, local organic resources and nitrogen fertilizer combinations affect maize productivity, soil structure and nutrient balances in semi-arid Kenya. Nutrient Cycling in Agroecosystems 90: 213-225.

Klute, A. (1986) Physical and mineralogical methods. In: "Physical and Mineralogical Methods", Part 1, $2^{\text {nd }}$ ed., ASA-SSSA-Agronomy, Madison, Wisconsin, USA.

Lal, R. (2009) "Soil Carbon Sequestration and the Greenhouse Effect", SSSA Special Publication no. 57, $2^{\text {nd }}$ ed., Madison, Wisconsin, USA.

Egypt. J. Soil Sci. 54, No. 2 (2014) 
Lal, R. (2004) Soil carbon sequestration impacts on global climate change and food security. Science 304: 1623-1627.

Lal, R. and Kimble, J.M. (1997) Conservation tillage for carbon sequestration. Nutr. Cycl. Agroecosys 49: 243-253.

Lashof, D.A. and Ahuja, D.R. (1990) Relative contributions of greenhouse gas emissions to global warming. Nature. 344: 529-531.

Majumder, B., Mandal, B., Bandyopadhyay, P. K., Gangopadhyay, A., Mani, P.K., Kundu, A.L. and Mazumdar, D. (2008) Organic amendments influence soil organic carbon pools and rice-wheat productivity. Soil. Sci. Soc. Am. J. 72: 775-785.

McCarl, B.A. and Schneider, U.A. (2001) Greenhouse Gas Mitigation in U.S. Agriculture and Forestry. Science 294: 2481-2482.

Melero, S., López-Bellido, R.J., López-Bellido, L., Muñoz-Romero, V., Moreno, F., Murillo, J.M. and Franzluebbers, A.J. (2012) Stratification ratios in a rainfed Mediterranean Vertisol in wheat under different tillage, rotation and $\mathrm{N}$ fertilisation rates. Soil Till. Res. 119: 7-12.

Mylavarapu, R.S. and Zinati, G.M. (2009) Improvement of soil properties using compost for optimum parsley production in sandy soils. Sci. Hort-Amsterdam 120: 426-430.

Ozores-Hampton, M., Stansly, P.A. and Salame, T.P. (2011) Soil Chemical, Physical, and Biological Properties of a Sandy Soil Subjected to Long-Term Organic Amendments. J. Sustain Agr. 35: 243-259.

Page, A.L., Miller, R.H. and Keeney, D.R. (1982) "Methods of Soil Analysis Part 2Chemical and Microbiological Properties. Part II ", Madison, USA, ASA-SSSA. Agronomy.

Parkin, T.B. and Kaspar, T.C. (2003) Temperature Controls on Diurnal Carbon Dioxide Flux. Soil. Sci. Soc. Am. J. 67: 1763-1772.

Powlson, D.S., Whitmore, A.P. and Goulding, K.W.T. (2011) Soil carbon sequestration to mitigate climate change: a critical re-examination to identify the true and the false. Eur. J.Soil.Sci. 62: 42-55.

Pramer, D. and Schmidt, E.L. (1964) "Experimental Soil Microbiology", Burgess Publishing Company, Minnesota, USA.

Ramadan, R. and Thomas, A. (2011) Evaluating the impact of reforming the food subsidy program in Egypt: A mixed demand approach. Food Policy 36: 638-646.

Rasool, Rehana, Kukal, S.S. and Hira, G.S. (2008) Soil organic carbon and physical properties as affected by long-term application of FYM and inorganic fertilizers in maize-wheat system. Soil. Till. Res. 101: 31-36. 
Sainju, U.M., Lenssen, A.W., Caesar-TonThat, T., Jabro, J., Lartey, R.T., Evans , R.G. and Allen, B. (2011) Dryland residue and soil organic matter as influenced by tillage, crop rotation, and cultural practice. Plant Soil 338: 27-41.

Shariatmadari, H., Shirvani, M. and Jafari, A. (2006) Phosphorus release kinetics and availability in calcareous soils of selected arid and semiarid toposequences. Geoderma 132 : 261-272.

Seleiman, M.F., Abdel-Aal, S.M., Ibrahim, M.E. and Monneveux, P. (2010) Variation of yield, milling, technological and rheological characteristics in some Egyptian bread wheat (Triticum aestivum L.) cultivars. Emir. J. Food. Agric. 22: 84-90.

Shehata, S.M. (1972) Evolution of some biological tests as parameters for microbi activities related to soil fertility. Ph.D. Thesis, Faculty of Agriculture, Cairo University.

Shehata, A.M.A. and Mohammad, S.I. (2010) Food security in Egypt. In Food security in Egypt, The $32^{\text {nd }}$ Reca Seminar on food security-Global trends and perspective. IDACA, Tokyo, Japan, Afro-Asian, Rural Development Organization (AARDO), New Delhi.

Shiferaw, B., Prasanna, B.M., Hellin, J. and Bänziger, M. (2011) Crops that feed the world 6. Past successes and future challenges to the role played by maize in global food security. Food Security 3: 307-327.

Sommer, R., Ryan, J., Masri, S., Singh, M. and Diekmann, J. (2011) Effect of shallow tillage, moldboard plowing, straw management and compost addition on soil organic matter and nitrogen in a dryland barley/wheat-vetch rotation. Soil Till. Res. 115-116: $39-46$.

Stakman, W.P. and van der Harst, G.G. (1962) The use of the pressure membrane apparatus to determine soil moisture contents at $\mathrm{pF} 3.0$ tot $\mathrm{pF} 4.2$ inclusive. [Wageningen]: Instituut voor Cultuurtechniek en Waterhuishouding.

Steiner, C., Teixeira, W.G., Lehmann, J., Nehls, T., Macêdo, J.L.V., Blum, W.E.H. and Zech, W. (2007) Long term effects of manure, charcoal and mineral fertilization on crop production and fertility on a highly weathered Central Amazonian upland soil. Plant Soil 291: 275-290.

Swift, R.S. (2001) Sequestration of carbon by soil. Soil Science 166: 858-871.

USDA (2012) Wheat and corn production on the rise. Egypt-Grain and Feed Annual. Accessed 2 April , 2012.

Wallace, T. (2010) Beginning and intermediate algebra. Creative Commons Attribution .

Weber, J., Karczewska, A., Drozd, J., Licznar, M., Licznar, S., Jamroz, E. and Kocowicz, A. (2007) Agricultural and ecological aspects of a sandy soil as affected by the application of municipal solid waste composts. Soil Biol. Biochem. 39: 12941302 .

Egypt. J. Soil Sci. 54, No. 2 (2014) 
West, T.O. and Post, W.M. (2002) Soil Organic Carbon Sequestration Rates by Tillage and Crop Rotation. Soil Sci. Soc. Am. J. 66: 1930-1946.

Woodwell, G.M., Mackenzie, F.T., Houghton, R.A., Apps, M., Gorham, E. and Davidson, E. (1998) Biotic feedbacks in the warming of the earth. Climatic Change 40: $495-518$.

Wu, F. and Guclu, H. (2013) Global maize trade and food security: Implications from a social network model. Risk Analysis.

Zhao, Y., Wang, P., Li, J., Chen, Y., Ying, X. and Liu, S. (2009) The effects of two organic manures on soil properties and crop yields on a temperate calcareous soil under a wheat-maize cropping system. Eur. J. Agron. 31: 36-42.

(Received 10/10/2013; accepted 30/10/2013) 


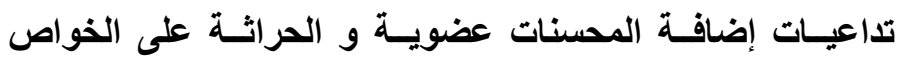
الفيزيائية لتربة رملية و احتجاز الكربون بها و كنلك إنتاجيتها من

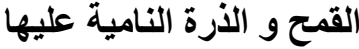

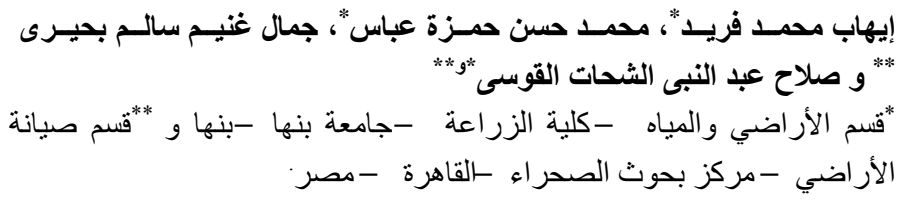

تلعب المادة العضوية دور ا هاما في تحسين خصوبة التربة ، خصوصا الرملية كما

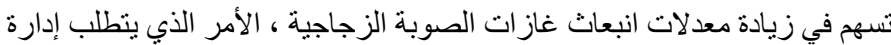

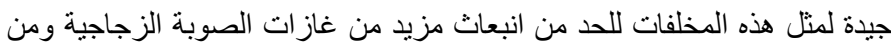

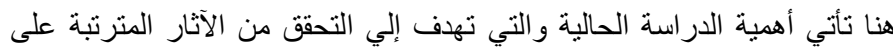

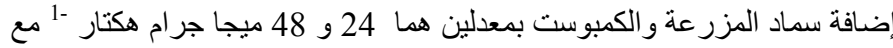

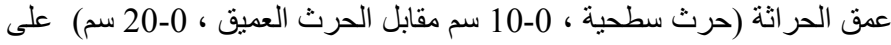

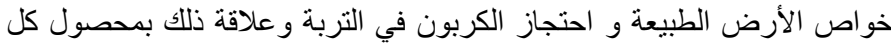

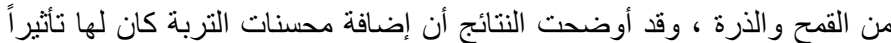

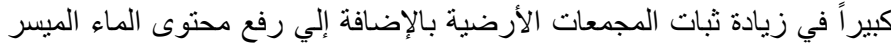

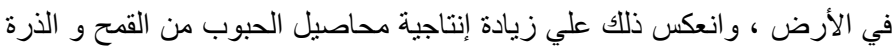

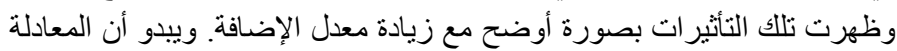

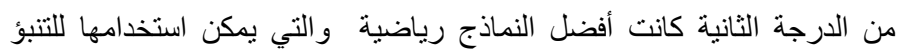

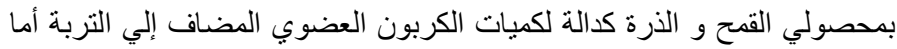

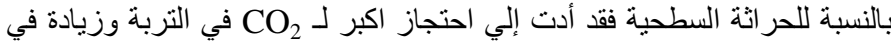
نسبة الكربون العضوي المتبقي بعد الزر اعة مقارنة بالحرث العميقة. 